\title{
Gradual cessation of milking reduces milk leakage and motivation to be milked in dairy cows at dry-off
}

\author{
G. Zobel, ${ }^{*}$ K. Leslie,† D. M. Weary, ${ }^{*}$ and M. A. G. von Keyserlingk*1 \\ *Animal Welfare Program, Faculty of Land and Food Systems, University of British Columbia, 2357 Main Mall, Vancouver, V6T 1Z4 Canada \\ †Department of Population Medicine, University of Guelph, 2536 Stewart Building, Guelph, N1G 2W1 Canada
}

\begin{abstract}
The effects of gradual versus abrupt cessation of milking at dry-off in dairy cows are not well understood, but gradually reducing milk production in human mothers is known to reduce discomfort and milk leakage. This study compared the effects of abrupt versus gradual cessation of milking on milk leakage and dairy cow behavior. Holstein dairy cows were housed in groups of 6 and randomly assigned to either abrupt milk cessation (i.e., dry-off on d 0) or gradual milk cessation (i.e., skipped milkings beginning on d 0 ; dry-off on d 5). Four replicates were performed over time, for a total of 24 cows (mean $\pm \mathrm{SD}$; parity $=2.3$ \pm 1.2 ; milk production the day before $\mathrm{d} 0=24 \pm 5$ $\mathrm{kg} / \mathrm{d}$ ). Intramammary antibiotic, internal teat sealer, and external teat sealant were administered at dry-off. Measurements were taken from $\mathrm{d}-3$ to 8 relative to dry-off. Three periods were identified for behavior data: baseline ( $\mathrm{d}-3$ to 1 ), period 1 (abrupt cows dry, gradual cows milking; d 0-4), and period 2 (all cows dry; d 5-8). Lying time was recorded with data loggers. Video scan samples (5-min intervals) were used to measure feeding time and motivation to be milked (i.e., standing at the pen's exit gate). Milk leakage was monitored every 20 min during the 2 -h period following the milking times of 0500 and $1500 \mathrm{~h}$ after complete cessation of milking (period 1 for abrupt vs. period 2 for gradual). Composite milk samples were taken before dry-off (d $-1,0$, and 5$)$ and at the start of the next lactation (colostrum, $24 \mathrm{~h}$ and 7-10 d postcalving) to determine somatic cell score (SCS) and conduct bacteriological examinations in clinical mastitis cases. Regardless of treatment, dry-off resulted in reduced lying time [14.1 vs. $13.2 \mathrm{~h} / \mathrm{d}$; standard error of the difference $(\mathrm{SED})=$ 0.2 ], reduced lying bouts (10.7 vs. 8.3 bouts/d; SED = 0.2 ), increased lying bout duration (1.4 vs. $1.7 \mathrm{~h} /$ bout; $\mathrm{SED}=0.03)$ and increased feeding time (5.0 vs. 5.9 $\mathrm{h} / \mathrm{d}$; SED $=0.2)$. Compared with baseline, the odds of
\end{abstract}

Received December 18, 2012.

Accepted May 5, 2013.

${ }^{1}$ Corresponding author: nina@mail.ubc.ca standing at the gate increased for abrupt cows (period 1: odds ratio $=6.2 ; 95 \%$ CI: $2.7-14.4$; and period 2: odds ratio $=5.2 ; 95 \%$ CI: $1.8-14.6)$. No increase in time spent standing at the gate was noted in gradual cows. Frequency of leakage was greater in abrupt versus gradual cows (75 vs. 27\%). Although the gradual treatment showed an increase in SCS over the $5 \mathrm{~d}$ of reduced milking frequency, both treatments showed an increase in SCS at calving and both returned to preexperiment levels within 7 to $10 \mathrm{~d}$ after calving. This work demonstrates that gradually reducing milking frequency in high-producing cows results in reduced time spent anticipating milking and reduced milk leakage after dry-off.

Key words: welfare, behavior, milking frequency, mastitis

\section{INTRODUCTION}

To promote udder health, calf development, and production in the subsequent lactation in dairy cows, milking typically ends approximately 40 to $60 \mathrm{~d}$ before calving (Kuhn et al., 2005). Earlier work suggested that gradual reduction in milking frequency at dry-off resulted in fewer new IMI at calving (Natzke et al., 1975). However, as blanket dry-cow antibiotic therapies have become common, abrupt cessation of milking is now frequently recommended for achieving dry-off (e.g., Blowey and Edmondson, 2010). It has been reported that cows may still be producing 25 to $30 \mathrm{~kg} / \mathrm{d}$ of milk at the time of abrupt dry-off (Stefanon et al., 2002). Early in the involution process milk continues to be produced, creating cisternal, duct, and alveoli engorgement (Oliver and Sordillo, 1989). The continued milk production creates increased intramammary pressure in cows with skipped milking frequency (O'Driscoll et al., 2011) and when milking is completely ceased (Cousins et al., 1980; Oliver and Sordillo, 1989). It has been suggested that increases in udder pressure may result in udder discomfort (O'Driscoll et al., 2011). An indirect way of identifying discomfort due to increased udder pressure is to measure changes in lying and standing time (Medrano-Galarza et al., 2012). A cow may opt to 
stand for longer and have more changes between standing and lying when her udder is full and distended (Österman and Redbo, 2001). Reduction in lying time has been noted when milkings are skipped (Stefanowska et al., 2000). The merit of lying behavior as an indicator of discomfort is supported by work examining the effect of an intramammary treatment of casein hydrolysate at dry-off on udder pressure. Cows treated with the hydrolysate had decreased udder pressure and spent more time lying down compared with cows that did not receive the treatment (Leitner et al., 2007).

Preventing highly motivated behavior by cows may result in frustration and displacement activities (Munksgaard and Simonsen, 1996). High-producing cows (i.e., $>25 \mathrm{~kg}$ of milk production/d) stand more when milking frequency is reduced, displaying increased restlessness and standing at the gate, presumably in anticipation of milking (Pomiès et al., 2007). Rathore (1982) suggested being milked is pleasant for high-producing cows, as evidenced by their entering the milking parlor earlier than lower producing cows. Furthermore, it has been suggested that incontinentia lactis (e.g., nonstimulated milk let down) can be triggered before entering the milking parlor (Rovai et al., 2007); cows that are highly motivated to leave the pen for milking may be more likely to experience this milk leakage.

The risk of increased IMI in the next lactation is greatest for high-producing cows (Rajala-Schultz et al., 2005). Cows dried off while producing in excess of 21 $\mathrm{kg} / \mathrm{d}$ are 1.8 times as likely to experience delayed teat canal closure (Dingwell et al., 2004). As milk leakage is a risk factor for increased IMI (Klaas et al., 2005), the use of dry-off methods that limit milk leakage may be advantageous. The aim of this study was to assess the effects of abrupt versus gradual cessation of milking on lying behavior, standing at the gate, and milk leakage in dairy cows.

\section{MATERIALS AND METHODS}

\section{Animals, Housing, and Diet}

This experiment was conducted at the University of British Columbia's Dairy Education and Research Centre (Agassiz, Canada) from May 2011 to July 2011. Cows were cared for according to the guidelines set by the Canadian Council on Animal Care (2009). Twentyfour Holstein cows (mean $\pm \mathrm{SD}$; parity $=2.3 \pm 1.8$; milk production $=24 \pm 5 \mathrm{~kg} / \mathrm{d} ; \mathrm{DIM}=319 \pm 35 \mathrm{~d})$ were used in this experiment ( 6 cows per replicate, with 4 replicates over time). All replicates were housed in the same pen. Cows were housed at $50 \%$ stocking density, with 12 deep, sand-bedded stalls and 12 headlocks as a feed barrier. Cows were moved into the pen on $d$
-4 relative to dry-off and fed a TMR (DM: $48 \%, \mathrm{CP}$ : 14.2\% DM, ADF: $27.5 \%$ DM, NDF: $41.0 \%$ DM). On d 0 , the diet was switched to ad libitum oat straw (DM: 93\%, CP: $6.7 \%$ DM, ADF: $46.7 \%$ DM, NDF: $68.7 \%$ $\mathrm{DM})$ and approximately $10 \mathrm{~kg}$ of tall fescue grass hay (DM: 93\%, CP: 16.4\% DM, ADF: 29.7\% DM, NDF: $49.1 \%$ DM) per cow. Cows had ad libitum access to clean water from an automatic water trough.

\section{Experimental Design and Behavioral Measurements}

Within each replicate of 6 animals, cows were assigned to pairs (matched for $305 \mathrm{~d}$ of milk production and parity), with 1 cow from each pair randomly assigned to 1 of 2 experimental treatments: (1) abrupt cessation of milking or (2) gradual cessation of milking consisting of a series of single-missed and double-missed milkings (d 0-2 = morning milking only; $\mathrm{d} 3=$ afternoon milking only; $\mathrm{d} 4=$ no milking; $\mathrm{d} 5=$ morning milking and dryoff). Cows were milked twice daily, at 0500 and 1500 h, before dry-off. On d 0, abrupt cows were milked and then completely dried-off; gradual cows were dried-off on d 5. Dry cow antibiotic (CEFA-DRI, BoehringerIngelheim, Burlington, ON, Canada) and internal teat sealer (Orbseal, Pfizer Inc., Kirkland, QC, Canada) therapy were administered at dry-off. All teats were also sealed externally (Gladiator Super Dry, BouMatic, Madison, WI).

Behavior and milk leakage were observed from $\mathrm{d}-3$ to 8 relative to the first skipped milking. Behavioral data were categorized for 3 periods: period 0 (baseline; $\mathrm{d}-3$ to $\mathrm{d}-2$ ), period 1 (abrupt cows dry, gradual cows milking; d 0-4), and period 2 (all cows dry; d 5-8).

Data loggers (HOBO Pendant G, Onset, Cape Cod, MA) were attached to the rear right hind leg and recorded leg position (i.e., lying or standing) every minute. Data were summarized to calculate daily lying time, lying bouts, and lying duration per cow according to the methods outlined by Ledgerwood et al. (2010).

Video captured by a Panasonic WV-CW504SP camera fixed above the pen was continuously recorded by a GeoVision 1480 digital recorder (USA Vision Systems, Irvine, CA). Motivation to be milked (i.e., standing at the gate) was defined as the cow standing in the raised area $(2.8 \times 3.3 \mathrm{~m})$ directly in front of the pen's rear exit gate, which cows would typically use to go to and from milking. Cows rarely visited this area, bordered on 3 sides by the gate, the neighboring pen, and a concrete divider from the lying stalls, unless they were leaving the pen. Cows had to have at least 2 front legs in this area to be scored as standing at the gate. As the gate faced away from the milking parlor, cows could be oriented in any direction on the raised area. We first watched the video continuously for $3 \mathrm{~d}$, and then 5 -min 
scan samples from the same $3 \mathrm{~d}$. As the scan samples correctly estimated $95 \%$ of the time spent standing at the gate, they were used to determine this time during the 3 -h periods after milking activities in the barn had ceased (0800-1000 and 1800-2000 h). Feeding behavior was anticipated to change in relation to the change in feed offered at dry-off, and was assessed by means of the 5-min video scan samples (Endres et al., 2005). Cows were coded as feeding if their heads were through the headlock feed barrier.

Milk leakage was monitored every $20 \mathrm{~min}$ for 2 -h periods beginning at the onset of each milking time $(0500$ and $1500 \mathrm{~h}$ ). The teat ends of each cow were observed for $5 \mathrm{~s}$ and scored as leaking if any teat was seen to be leaking or streaming milk. Cows lying down during this period were not disturbed and, therefore, these data were excluded from the total number of observations (mean number of observations excluded per cow $=39 \pm$ $14 \%)$. A percent of the number of leaking observations out of the total number of observations was calculated for each cow. Overall leakage incidence was summarized as either 0 (no milk leakage observed during all $4 \mathrm{~d}$ ) or 1 (milk leakage observed at some point over the $4 \mathrm{~d}$ ).

Composite milk samples were taken on $\mathrm{d}-1$ (gradual and abrupt), 0 (abrupt), 5 (gradual), as well as first colostrum on $\mathrm{d} 1$ and 7 to 10 after calving (gradual and abrupt). Milk samples were analyzed for SCC and bacteria by Maritime Quality Milk (Atlantic Veterinary College, University of Prince Edward Island, Charlottetown, Canada). A logarithm transformation [SCS = $\log 2(\mathrm{SCC} / 100,000)+3]$ was used to convert SCC to SCS. To determine a baseline pre-dry-off SCS for each treatment, the $\mathrm{d}-1$ sample was compared with each group's last milking. As an increase had been noted from $\mathrm{d}-1$ to 5 in the gradual group, treatments were tested separately over time.

\section{Statistical Analysis}

For all behavior data, d 0 and 4 to 6 in replicate 3 were removed from the final data set owing to management changes. Experimental day was corrected to start at the afternoon milking, as this is when cows would notice a change in their routine.

Milk Production. Daily milk production data were collected for $\mathrm{d}-4$ to 0 (for abrupt) and $\mathrm{d}-4$ to 5 (for gradual) from the computerized milking and management software system, Dairy Comp 305 (Valley Agricultural Software, Tulare, CA).

Milk Leakage. One cow was removed from the data set owing to leakage during the baseline period. For testing the effect of treatment, overall leakage incidence (either leaking or not leaking) was tested with a 2-tailed Fisher's exact test.
Lying and Feeding Behavior and SCS. The effect of treatment on lying time, lying bouts, feeding time, and SCS was tested with mixed model ANOVA in SAS (PROC MIXED; SAS Institute Inc., Cary, NC). Period was used as a repeated measure, with milk production at dry-off, DIM, parity (primiparous and multiparous), and weight as covariates and replicate and replicate $x$ treatment as random effects. The residual term of the model was cow (replicate $\times$ treatment) and the error term to test the effect of experimental group was replicate $\times$ treatment. The covariance structure selected for all models was an auto-regressive type 1 based on the lowest Akaike's information criterion. Residuals were examined for all models to verify normality and homogeneity of variances and to detect possible outliers and influential observations.

Standing at the Gate. The number of times a cow was seen standing at the gate was summarized per cow per period, and then converted to a percent (time standing at the gate out of total observation time). The first replicate was not included because of a difference in pen exit gates compared with subsequent replicates. A logit-transformation with a bias correction factor of 0.25 (Cox and Snell, 1970) was applied to the proportion of times cows were by the gate out of the total observation time, to meet the assumptions of normality and homogeneity of variance and to ensure the estimates and confidence interval were calculated correctly. Data were analyzed using mixed models in SAS (PROC GLIMMIX) that included period as a repeated measure over cow, treatment, and parity (primiparous or multiparous) as fixed effects, biologically plausible 2-way interactions between fixed effects, milk production at dry-off as a covariate and replicate and replicate $x$ treatment as random effects. The residual term of the model was cow (replicate $\times$ experimental group) and the error term to test the effect of experimental group was replicate $\times$ experimental group. An auto-regressive type 1 covariance structure was selected based on the smallest Akaike's information criterion. Dunnett's 2-tailed test was used as a post hoc test of differences between baseline and subsequent days. Residuals were examined to verify normality and homogeneity of variances, and to detect possible outliers and influential points. Coefficients were back-transformed and results presented as odds ratio and confidence interval. The odds ratio expresses how much higher the odds of displaying a behavior are during a period as compared with the baseline period.

\section{Milk Production}

\section{RESULTS}

No decrease in milk production was noted for either treatment in the $4 \mathrm{~d}$ before dry-off $(P>0.1)$. Milk 
Table 1. Percent of total observations in which cows were leaking for abrupt and gradual dry-off treatments, as well as milk production of both leaking and nonleaking cows

\begin{tabular}{|c|c|c|c|c|c|c|}
\hline \multirow[b]{2}{*}{ Item } & \multicolumn{3}{|c|}{ Abrupt dry-off $(\mathrm{n}=12)$} & \multicolumn{3}{|c|}{ Gradual dry-off $(\mathrm{n}=11)$} \\
\hline & Mean & $\mathrm{SD}$ & Range & Mean & $\mathrm{SD}$ & Range \\
\hline Last milking milk production (cows that did not leak), ${ }^{1} \mathrm{~kg} / \mathrm{d}$ & 15.7 & 3.6 & $11.5-18.0$ & 9.5 & 3.7 & $5.5-16.0$ \\
\hline
\end{tabular}

${ }^{1}$ Last milking day dependent on experimental group (abrupt $=\mathrm{d} 0$; gradual $=\mathrm{d} 5$ ).

production did not differ between treatments on the day before dry-off, averaging 24.2 and $23.8 \mathrm{~kg} / \mathrm{d}$ in the abrupt and gradual treatments, respectively [standard error of the difference $($ SED) $=1.3$, not significant]. During the $5 \mathrm{~d}$ of skipped milkings in the gradual treatment, milk production declined (on average $0.6 \mathrm{~kg} / \mathrm{d}$; $P<0.0001)$. Production for the gradual cows averaged $10.9 \mathrm{~kg}$ at final milking before complete dry-off compared with $14.1 \mathrm{~kg}$ for abrupt cows $(\mathrm{SED}=1.2 ; P$ $<0.02)$.

\section{Behavior}

Lying time, frequency of lying bouts, lying bout duration, and feeding time changed with period. After dry-off, lying time decreased from 14.1 vs. $13.2 \mathrm{~h} / \mathrm{d}$ $(\mathrm{SED}=0.2 ; P<0.0001)$. Lying bouts decreased from 10.7 to 8.3 (SED $=0.2 ; P<0.0001$ ). Lying bout duration increased from $(1.4$ vs. $1.7 \mathrm{~h} /$ bout; $\mathrm{SED}=0.03$; $P<0.0001)$ and feeding time increased from 5.0 vs. $5.9 \mathrm{~h} / \mathrm{d}(\mathrm{SED}=0.2 ; P<0.0001)$. However, treatment did not have an effect on these behaviors $(P>0.05$ for treatment and treatment $\times$ period). Cows that produced more milk before dry-off spent less time lying down after dry-off (coefficient estimate $=-7.8 \pm$ $3.6 \mathrm{~min} / \mathrm{d} ; P=0.04$ ). Heavier cows had longer bout duration after dry-off (coefficient estimate $=8.9 \pm 3.8$ $\mathrm{min} / \mathrm{d}$ for each $100 \mathrm{~kg}$ increase in BW; $P=0.04)$. Cows producing more milk had increased feeding time (coefficient estimate $=4.4 \pm 1.5 \mathrm{~min} / \mathrm{d} ; P=0.01)$. Heavier cows spent less time eating (coefficient estimate $=-0.3$ $\pm 0.1 \mathrm{~min} / \mathrm{d}$ for every $100 \mathrm{~kg}$ increase in $\mathrm{BW} ; P=0.01$ ) compared with lighter cows.

\section{Milk Leakage and SCS}

Over the course of the 4 observation days following complete cessation of milking, more abrupt cows $(9 / 12)$ leaked compared with gradual cows $(3 / 11$; Fisher's exact test, $P=0.04$ ). Abrupt cows began leaking 1 $\mathrm{d}$ after dry-off, and leaking continued for the next 2 d of observation. Gradual cows were observed leaking milk only on d 3. Of the cows that leaked after dry-off, abrupt cows leaked for a higher percentage of the total observations. Milk production before dry-off did not differ between cows that later leaked or did not leak milk (Table 1).

Treatment did not have an effect on SCS $(P>0.05$ for treatment and treatment $\times$ sample). No difference was observed between $d-1$ and final milking (d 0) SCS for abrupt cows. However, after removal of 1 outlier, which was having undue influence on SCS before dryoff, the gradual treatment's SCS increased between d -1 and final milking (d 5; 2.3 vs. 3.7 ; SED $=0.6 ; P=$ 0.04). Therefore, changes in SCS from baseline to after calving were tested separately for each treatment. Both treatments returned to below pre-dry-off levels within 7 to $10 \mathrm{~d}$ after calving (Table 2). Days in milk, milk production at final milking, and parity had no effect on SCS in either model. Three cows developed clinical mastitis after calving; specifically, 1 gradual cow became infected with Staphylococcus spp. (CNS) $+E$. coli, Enterobacter spp., another gradual cow became infected with Staphylococcus spp. (CNS), and 1 abrupt cow became infected with Corynebacterium spp.

\section{Standing at the Gate}

The percent of time spent standing at the gate was highly variable among cows, but standing time at the gate was low for both treatments during the baseline period (mean \pm SD: $0.5 \pm 0.8 \%$ of total observation time). An interaction effect was noted between period and treatment $(P<0.001)$. The gradual treatment showed no increase in standing at the gate from baseline to periods 1 and 2 . The odds of cows in the abrupt treatment standing at the gate were greater by a factor of 6.2 in period 1 and 5.2 in period 2 compared with the baseline period (Table 3 ).

\section{DISCUSSION}

Abrupt cessation of milking at drying off is commonly used in the dairy industry (Blowey and Edmondson, 2010). The fact that many cows are able to maintain high levels of milk production even at the end of their lactation (Dingwell et al., 2001; Stefanon et al., 2002) 
Table 2. Changes in SCS after calving compared with baseline samples taken for each treatment on the last day of milking (abrupt $=\mathrm{d} 0$, gradual $=\mathrm{d} 5$ )

\begin{tabular}{lcccccccc}
\hline & \multicolumn{2}{c}{ Abrupt dry-off ${ }^{1}(\mathrm{n}=12)$} & & \multicolumn{2}{c}{ Gradual dry-off $^{2}(\mathrm{n}=10)$} \\
\cline { 2 - 3 } \cline { 7 - 8 } SCS & Estimate & SED & P-value & & Estimate & SED & $P$-value \\
\hline Colostrum & 2.7 & 0.5 & $<0.0001$ & & 1.1 & 0.5 & 0.02 \\
24 h after calving & 1.6 & 0.5 & 0.02 & & 0.7 & 0.5 & 0.22 \\
7 to 10 d after calving & -0.6 & 0.5 & 0.3 & & -2.4 & 0.6 & $<0.0001$ \\
\hline
\end{tabular}

${ }^{1}$ Abrupt dry-off baseline SCS (mean \pm SD; $2.3 \pm 1.4$ ).

${ }^{2}$ Gradual dry-off baseline SCS (mean \pm SD; $3.7 \pm 1.3$ ).

may pose risks for udder health (e.g., increased IMI due to delayed teat-canal plug formation and milk leakage; Schukken et al., 1993; Dingwell et al., 2004) and cow welfare (e.g., hunger due to the need to reduce milk production through dramatic diet changes; Valizaheh et al., 2008; Tucker et al., 2009) when subjected to common dry-off procedures. Reducing milk production can also be achieved by skipping milkings (Bushe and Oliver, 1987; Davis et al., 1998), as increased milk stasis induces mammary apoptosis (programmed cell death; Wilde et al., 1997). In humans, a gradual reduction in milking frequency reduces milk production, milk leakage, and discomfort (Betzold, 2007; Lawrence and Lawrence, 2011). Human and bovine mammary systems are anatomically different, probably resulting in different interpretations of mammary pressure by humans and cows. For instance, in the cow, milk is transported through primary ducts to the cisterns. These cisterns have been shown to have great milk storage capacity even after $24 \mathrm{~h}$ of milk cessation, only reaching full capacity after $40 \mathrm{~h}$ (Davis et al., 1998). Conversely, in humans, milk is transported through lactiferous ducts, and, although they widen into areas once considered to be lactiferous sinuses, the structure of sinuses is lacking; hence, the human breast has less capacity for milk storage (Ramsay et al., 2005) compared with the cow udder. Therefore, it is possible that the storage capacity of the bovine udder allows for a much larger milk fill proportionally, compared with the human, before discomfort is felt. Nonetheless, in high-producing cows that are abruptly dried-off, it is possible that cisternal pressure may reach a threshold at which the cows do feel discomfort. Evidence exists that, in some instances, cows do alter their lying behavior in a way indicative of udder pressure avoidance (e.g., Österman and Redbo, 2001). Thus, it was hypothesized that high-producing cows would experience milk leakage and discomfort when milking was ceased abruptly, and that the discomfort could be indirectly assessed through changes in lying behavior and motivation to be milked.

Previous work demonstrated that omitted milkings (O'Driscoll et al., 2011) and reduced milking frequencies (Österman and Redbo, 2001) resulted in decreased lying time that was attributed to milk accumulation and the resulting udder pressure. Furthermore, Leitner et al. (2007) demonstrated that when udder fill was minimized with casein hydrolysate cows lay for longer periods of time. In the present study, cows in both treatments showed a reduction in lying time and frequency of lying bouts and increased bout duration. These changes in lying behavior may be explained, in part, by the change in feeding management that was implemented as part of the dry-off routine. The change in feed from a highly palatable, high-energy TMR to a low-energy combination of grass hay and ad libitum straw resulted in a $19 \%$ increase in daily feeding time. In previous work examining feed management changes similar to those used in the present study, similar increases in feeding time were observed (Valizaheh et al., 2008). As DMI was not measured in the current study,

Table 3. Changes in the logit-transformed proportion of times cows $(n=18)$ were observed standing at the gate during the 3-h periods following cessation of all milking activities in the barn (0800-1000 and 1800-2000 h) for period 1 (abrupt treatment dried off, gradual treatment still milking intermittently) and period 2 (both treatments dry) as compared with baseline

\begin{tabular}{lccccc}
\hline $\begin{array}{l}\text { Standing } \\
\text { at gate }\end{array}$ & $\begin{array}{c}\text { Parameter } \\
\text { estimate }\end{array}$ & SE & $\begin{array}{c}\text { Odds } \\
\text { ratio }\end{array}$ & $95 \%$ CI & $P$-value \\
\hline $\begin{array}{l}\text { Period 1 } \\
\text { Abrupt dry-off }\end{array}$ & 1.8 & & & & \\
$\quad$ Gradual dry-off & -0.3 & 0.4 & 6.2 & $2.7-14.4$ & $<0.0001$ \\
Period 2 & & 0.4 & 0.7 & $0.3-1.7$ & 0.56 \\
$\quad \begin{array}{l}\text { Abrupt dry-off } \\
\text { Gradual dry-off }\end{array}$ & 1.6 & 0.5 & 5.2 & $1.8-14.6$ & 0.002 \\
\hline
\end{tabular}


increased feeding time as a consequence of increased udder discomfort could not be disentangled from increased time required to consume the lower energy diet. Further work should separate these factors, as well as incorporate an evaluation of udder firmness as a secondary measure of the identifying the discomfort cows experience from udder fill.

The late stage of lactation may have also affected the lying behavior of the cows used in the present study. O'Driscoll et al. (2011) found changes in lying behavior when milkings were skipped, but this finding was for cows at about 90 DIM. Similarly, Österman and Redbo (2001) found changes in lying behavior when milking frequencies were altered, but these authors used cows producing 38 to $40 \pm 5 \mathrm{~kg} / \mathrm{d}$, approximately $15 \mathrm{~kg} / \mathrm{d}$ greater than the cows in the current trial. Cows at lower milk production may plausibly experience less discomfort due to udder fill, muting the effects of dryoff method on changes in lying behavior. Consistent with this suggestion, Tucker et al., (2007) failed to observe changes in lying time when milking frequencies were altered in cows producing $16.5 \pm 4.1 \mathrm{~kg} / \mathrm{d}$.

In addition to potential discomfort, udder pressure increases the chances of milk leakage (Rovai et al., 2007). Schukken et al. (1993) reported that cows that leaked at dry-off tended to develop clinical mastitis during the dry period. Protection of the udder against IMI during the dry-period is helped by ensuring that each teat canal has a fully formed keratin plug. In one study, $97 \%$ of the quarters that were diagnosed with clinical mastitis had no keratin plug (Williamson et al., 1995). Therefore, practices that promote teat-canal keratin plug formation, such as lowering milk production at dry-off (Dingwell et al., 2004), should be encouraged. Cows in the current study were all treated with an intramammary antibiotic, as well as both an internal teat sealer and an external teat sealant. Several studies have shown the efficacy of the internal sealer for preventing new cases of clinical mastitis, even when used without an antibiotic (Berry and Hillerton, 2002; Huxley et al., 2002; Bhutto et al., 2011). However, these trials targeted IMI incidence; detailed monitoring of leakage for a period after dry-off was not a focus. Also, the efficacy and adherence of external teat sealants has been documented, but not evaluated for prevention of leaking (Lim et al., 2007). The current study was not designed to identify treatment effects on SCS and IMI, but some discussion is warranted.

First, SCS was found to increase between the start of the gradual milking frequency and the final milking. Numerous studies show that reduced milking frequency increases SCC; however, this increase does not correspond to increases in mastitis-causing pathogens (reviewed in Stelwagen et al., 2013). When consider- ing a reduction in milking frequency as part of dryoff, early work demonstrated that all cows, regardless of dry-off technique, had increased SCC (Bushe and Oliver, 1987). This work also suggested that, in cows where milking was gradually reduced and paired with a reduced energy diet, as in the current trial, mammary secretions were actually more inhibitory to certain bacterial growths than were those of cows which had their milking ceased abruptly. The current trial did not measure somatic cells in cows beyond their last milking, but it is possible that the SCS increase seen over the $5 \mathrm{~d}$ of gradually reduced milking frequency could have occurred in the abruptly dried-off cows as well. It is important to note that Bushe and Oliver (1987) started their study using cows with milk production substantially lower than that in the current trial $(\sim 13$ $\mathrm{kg} / \mathrm{d}$ ). Therefore, further study is needed to examine abrupt versus gradual milking cessation on SCS in cows with milk production more representative of current industry values (e.g., $>20 \mathrm{~kg}$ ), without the use of intramammary antibiotics.

Second, the descriptive results of IMI incidence may also be of interest. Of the 3 cows that developed clinical mastitis after calving, 2 were leaking at dry-off and at calving. Dingwell et al. (2004) found that almost a quarter of teats remained open 6 wk after dry-off, and it is possible that some cows develop IMI even when teat sealants are used. From the current findings it is suggested that leakage remains an issue, even with the use of internal teat sealers or external sealants.

Regardless of experimental treatment applied during dry-off, the teat sealer and sealant appeared to have a short-term benefit in that leakage was first observed approximately $24 \mathrm{~h}$ after dry-off. After this initial period, the overall leakage incidence was $52 \%$. This rate may be partially a function of milk production. Drying-off higher producing cows (e.g., above $21 \mathrm{~kg} / \mathrm{d}$, similar to those in this study) delays teat canal closure (Dingwell et al., 2004). Tucker et al. (2009) showed that when feed changes were not initiated to drop milk production, even cows producing $10 \mathrm{~kg} / \mathrm{d}$ at abrupt dry-off had leakage rates of over $40 \%$.

In the current study, both treatments had similar milk production, with no differences noted in milk production before dry-off. However, the gradual cows' milk production was reduced by $\mathrm{d} 5$. This reduction is probably at least in part due to the switch to a lower energy diet on d 0. Indeed, Bushe and Oliver (1987) demonstrated the effectiveness of this management practice before dry-off on reducing milk production. In the case of the present study, pairing a reduction in milking frequency with a change to a lower energy diet before dry-off achieved a substantial decrease in milk production at actual dry-off (Oliver and Sordillo 
1989). Nonetheless, actual milk production at final milking was similar in the leaky cows of both experimental treatments. Further work is needed to tease out whether other factors, such as the switch to a series of intermittent milkings before complete milk cessation, may also affect leakage. It should be noted that even cows dried off at much lower milk production (e.g., aim of $<5 \mathrm{~kg} / \mathrm{d}$ at dry-off) sometimes leak (Schukken et al., 1993), indicating that leakage is variable among cows. As a variety of factors contribute to milk leakage, including energy in the diet at dry-off (Tucker et al., 2009), high peak milk flow rate, short teats, teat canal protrusion, and inverted teat ends (Klaas et al., 2005), these factors should be considered in future work.

A contributing factor to leakage in the current study may have been the location of the pen. Although not in direct sight of the milking parlor, the pen was within $50 \mathrm{~m}$ of it, meaning that cows were likely aware of the milking activities. Munksgaard and Simonsen (1996) suggest that preventing animals from participating in an activity to which they are accustomed could cause frustration. As milking frequency reduction triggers an increase in standing at the gate around normal milking time (Pomiès et al., 2007), it was not surprising that in the current trial an increase in standing at the gate was noticed for up to $3 \mathrm{~h}$ after milking had ceased. However, standing at the gate only increased in the abruptly dried-off cows; the cows that were gradually reduced in milking frequency did not display increased standing behavior at the gate. Although it is not possible to discern whether the cows were motivated to stand at the gate simply owing to routine or whether they were feeling discomfort from udder fill, these cows did leak more often and for a longer period of time compared with cows that spent less time standing at the gate. This result agrees with that of Stefanowska et al. (2000), who showed that missed milkings triggered both increased standing and milk leakage. Because milk let down is triggered by auditory, visual, and other cues (e.g., presence of a calf; Pollock and Hurnik, 1978), increased standing at the gate in response to missed milking could have triggered milk leakage. The involution process does not begin immediately after milking is ceased (Capuco and Akers, 1999); udder pressure has been shown to increase markedly for at least the first 4 d following abrupt dry-off (Leitner et al., 2007). Relieving some of this pressure by intermittent milking in the gradually dried-off cows likely reduced the number of cows that leaked.

\section{CONCLUSIONS}

At dry-off, all cows responded with reduced lying times. Abruptly dried-off cows were more likely to stand at the gate following regular milking hours, during the entire 8-d observation period following dry-off, indicating that these cows were motivated to be milked. A gradual reduction in milking frequency reduced the amount and length of milk leakage, especially when milk production was high at dry-off. Gradual cessation of milking should be considered as a method of dry-off, especially for high-producing cows.

\section{ACKNOWLEDGMENTS}

The authors thank the staff and students at the University of British Columbia's Dairy Education and Research Centre and the University's Animal Welfare Program for assistance in the barn. Gosia Zobel was supported by Canada's Natural Science and Engineering Research Council's PGSD Scholarship (Ottawa, ON, Canada) and the Canadian Bovine Mastitis Research Network (Saint-Hyacinthe, Quebec, Canada). General funding for the Animal Welfare Program is provided by Canada's Natural Science and Engineering Council through the Discovery Program and the Industrial Research Chair Programs together with industry contributions from the Dairy Farmers of Canada (Ottawa, Canada), and many other donors listed on the Animal Welfare website at http://www.landfood.ubc. ca/animalwelfare/.

\section{REFERENCES}

Berry, E. A., and J. E. Hillerton. 2002. The effect of an intramammary teat seal on new intramammary infections. J. Dairy Sci. $85: 2512-2520$

Betzold, C. M. 2007. An update on the recognition and management of lactational breast inflammation. J. Midwifery Womens Health 52:595-605.

Bhutto, A. L., R. D. Murray, and Z. Woldehiwet. 2011. The effect of dry cow therapy and internal teat-sealant on intra-mammary infections during subsequent lactation. Res. Vet. Sci. 90:316-320.

Blowey, R., and P. Edmondson. 2010. Mastic control in dairy herds, 2nd ed. CAB International, Oxfordshire, UK.

Bushe, T., and S. P. Oliver. 1987. Natural protective factors in bovine mammary secretions following different methods of milk cessation. J. Dairy Sci. 70:696-704.

Canadian Council on Animal Care (CCAC). 2009. CCAC Guidelines on: The Care and Use of Farm Animals in Research, Teaching and Testing. CCAC, Ottawa, Canada.

Capuco, A. V., and R. M. Akers. 1999. Mammary involution in dairy animals. J. Mammary Gland Biol. Neoplasia 4:137-144.

Cousins, C. L., T. M. Higgs, E. R. Jackson, F. K. Neave, and F. H. Dodd. 1980. Susceptibility of the bovine udder to bacterial infection in the dry period. J. Dairy Res. 47:11-18.

Cox, D. R., and E. J. Snell. 1970. Analysis of Binary Data. 2nd ed. Chapman and Hall, London, UK.

Davis, S. R., V. C. Farr, P. J. A. Copeman, V. R. Carruthers, C. H. Knight, and K. Stelwagen. 1998. Partitioning of milk accumulation between cisternal and alveolar compartments of the bovine udder: Relationship to production loss during once daily milking. J. Dairy Res. 65:1-8.

Dingwell, R. T., D. F. Kelton, K. E. Leslie, and V. L. Edge. 2001. Deciding to dry-off: Does level of production matter? Pages 69-79 in Proc. Natl. Mastitis Counc. Ann. Mtg. National Mastitis Council, Madison, WI. 
Dingwell, R. T., K. E. Leslie, Y. H. Schukken, J. M. Sargeant, L. L. Timms, T. F. Duffield, G. P. Keefe, D. F. Kelton, K. D. Lissemore, and J. Conklin. 2004. Association of cow and quarter-level factors at drying-off with new intramammary infections during the dry period. Prev. Vet. Med. 63:75-89.

Endres, M. I., T. J. DeVries, M. A. G. von Keyserlingk, and D. M. Weary. 2005. Effect of feed barrier design on the behavior of loosehoused lactating dairy cows. J. Dairy Sci. 88:2377-2380.

Huxley, J. N., M. J. Green, L. E. Green, and A. J. Bradley. 2002. Evaluation of the efficacy of an internal teat sealer during the dry period. J. Dairy Sci. 85:551-561.

Klaas, I. C., C. Enevoldsen, A. K. Ersbøll, and U. Tölle. 2005. Cowrelated risk factors for milk leakage. J. Dairy Sci. 88:128-136.

Kuhn, M. T., J. L. Hutchison, and H. D. Lawrence. 2005. Characterization of days dry for United States Holsteins. J. Dairy Sci. $88: 1147-1155$.

Lawrence, R. A., and R. M. Lawrence. 2011. Breastfeeding: A Guide for the Medical Professional. 7th ed. Mosby (Elsevier Inc.), St. Louis, MO.

Ledgerwood, D. N., C. Winckler, and C. B. Tucker. 2010. Evaluation of data loggers, sampling intervals, and editing techniques for measuring the lying behavior of dairy cattle. J. Dairy Sci. 93:5129-5139.

Leitner, G., S. Jacoby, E. Maltz, and N. Silanikove. 2007. Casein hydrolyzate intramammary treatment improves the comfort behavior of cows induced into dry-off. Livest. Sci. 110:292-297.

Lim, G. H., K. E. Leslie, D. F. Kelton, T. F. Duffield, L. L. Timms, and R. T. Dingwell. 2007. Adherence and efficacy of an external teat sealant to prevent new intramammary infections in the dry period. J. Dairy Sci. 90:1289-1300.

Medrano-Galarza, C., J. Gibbons, S. Wagner, A. M. de Passillé, and J. Rushen. 2012. Behavioral changes in dairy cows with mastitis. J. Dairy Sci. 95:6994-7002.

Munksgaard, L., and H. B. Simonsen. 1996. Behavioral and pituitary adrenal-axis responses of dairy cows to social isolation and deprivation of lying down. J. Anim. Sci. 74:769-778.

Natzke, R. P., R. W. Everett, and D. R. Bray. 1975. Effect of drying off practices on mastitis infection. J. Dairy Sci. 58:1828-1835.

O'Driscoll, K., D. Gleeson, B. O'Brien, and L. Boyle. 2011. Does omission of a regular milking event affect cow comfort? Livest. Sci. 138:132-143.

Oliver, S. P., and L. M. Sordillo. 1989. Approaches to the manipulation of mammary involution. J. Dairy Sci. 72:1647-1664.

Österman, S., and I. Redbo. 2001. Effects of milking frequency on lying down and getting up behaviour in dairy cows. Appl. Anim. Behav. Sci. 70:167-176.
Pollock, W. E., and J. F. Hurnik. 1978. Effect of calf calls on rate of milk release of dairy cows. J. Dairy Sci. 61:1624-1626.

Pomiès, D., B. Martin, Y. Chiliard, P. Pradel, and B. Rémond. 2007. Once-a-day milking of Holstein and Montbéliarde cows for 7 weeks in mid-lactation. Animal 1:1497-1505.

Rajala-Schultz, P. J., J. S. Hogan, and K. L. Smith. 2005. Association between milk yield at dry-off and probability of intramammary infections at calving. J. Dairy Sci. 88:577-579.

Ramsay, D. T., J. C. Kent, R. A. Hartmann, and P. E. Hartmann. 2005. Hartmann Anatomy of the lactating human breast redefined with ultrasound imaging. J. Anat. 206:525-534.

Rathore, A. K. 1982. Order of cow entry at milking and its relationships with milk yield and consistency of the order. Appl. Anim. Ethol. 8:45-52.

Rovai, M., M. T. Kollmann, and R. M. Bruckmaier. 2007. Incontinentia lactis: Physiology and anatomy conducive to milk leakage in dairy cows. J. Dairy Sci. 90:682-690.

Schukken, Y. H., J. Vanvliet, D. Vandegeer, and F. J. Grommers. 1993. A randomized blind trial on dry cow antibiotic infusion in a low somatic cell count herd. J. Dairy Sci. 76:2925-2930.

Stefanon, B., M. Colitti, G. Gabai, C. H. Knight, and C. J. Wilde. 2002. Mammary apoptosis and lactation persistency in dairy animals. J. Dairy Res. 69:37-52.

Stefanowska, J., M. Plavsic, A. H. Ipema, and M. M. W. B. Hendriks. 2000. The effect of omitted milking on the behaviour of cows in the context of cluster attachment failure during automatic milking. Appl. Anim. Behav. Sci. 67:277-291.

Stelwagen, K., C. V. C. Phyn, S. R. Davis, J. Guinard-Flament, D. Pomiès, J. R. Roche, and J. K. Kay. 2013. Invited review: Reduced milking frequency: Milk production and management implications. J. Dairy Sci. 96:3401-3413.

Tucker, C. B., D. E. Dalley, J. L. K. Burke, and D. A. Clark. 2007. Milking cows once daily influences behavior and udder firmness at peak and mid lactation. J. Dairy Sci. 90:1692-1703.

Tucker, C. B., S. J. Lacy-Hulbert, and J. R. Webster. 2009. Effect of milking frequency and feeding level before and after dry off on dairy cattle behavior and udder characteristics. J. Dairy Sci. 92:3194-3203.

Valizaheh, R., D. M. Veira, and M. A. G. von Keyserlingk. 2008. Behavioural responses by dairy cows provided two havs of contrasting quality at dry-off. Appl. Anim. Behav. Sci. 109:190-200.

Wilde, C. J., L. H. Quarrie, E. Tonner, D. J. Flint, and M. Peaker. 1997. Mammary apoptosis. Livest. Prod. Sci. 50:29-37.

Williamson, J. H., M. W. Woolford, and A. M. Day. 1995. The prophylactic effect of a dry-cow antibiotic against Streptococcus uberis. N. Z. Vet. J. 43:228-234. 